\title{
The Impact of Airbnb Platforms on the Romanian Real Estate Market
}

\author{
Daniela RĂBOJ*
}

Faculty of Geodesy, Technical University of Civil Engineering Bucharest, 122-124 Lacul Tei Bd, Bucharest, Romania

*corresponding author: lacatusu_dani@yahoo.com

BulletinUASVM Horticulture 76(2) / 2019

Print ISSN 1843-5254, Electronic ISSN 1843-5394

DOI:10.15835/buasvmcn-hort: 2019.0036

\begin{abstract}
Airbnb or other similar platforms have evolved greatly in recent years and managed to change the perception of accommodation, in the same manner as Uber has changed the perception of public transport. Renting for tourism purposes, through Airbnb type platforms, has a direct impact on investors, state institutions, real estate markets and so on. The purpose of this paper is to analyze the effect of Airbnb type platforms on the Romanian real estate market and to describe the difficulties encountered in evaluating the properties that produce hotel rental income. These analyzes are intended in order to highlight an empirical perspective on this trend. The study consisted of a thorough online research, that took also into consideration legislation in force. In this paper I have presented a series of assessments of the impact on the market value of residential properties in Romania, which the properties listed for rent on Airbnb, seem to have.
\end{abstract}

Keywords: Airbnb, home-sharing, real estate, valuation

\section{Introduction}

Airbnb (air, bed and breakfast) is a platform available in over 190 countries and more than 34,000 cities, which facilitates short-term accommodation rentals. On the one hand, if you own an apartment or a room available, you can list it on the platform and find clients for them, thus having another source of income [6].

Shortly, Airbnb has become one of the most discussed topics in the hospitality sector. The service has become incredibly popular since its establishment in 2008, in San Francisco, with over 60 million users.

According to a study published by the companies "Exact Research and Consulting" and "WaveTreeZero", in Romania there are already over 10,000 homes that are listed on the platform, and $7 \%$ of young Romanians, aging between 15 and 34 , have already used this service [6]. The private homes promoted through this international platform are either apartments or single-family houses, or even one single room that is part of a residence, where the host lives daily.

The Airbnb site (www.airbnb.com) offers its users (for those who are looking for accommodation) a basic search engine with quick results, that allows afterwards a more selective filtering, based on the desired criteria (e.g.: neighborhood, number of rooms or price). In terms of the pricing mechanisms, Airbnb allows its hosts to solely adjust their prices, rather than to set up prices based on market conditions.

Payments are made through the Airbnb site, and the platform charges both tourists and hosts, with different percentages. An important aspect to be considered is the trust between hosts and tourists, as Airbnb is relying on its reputation. 


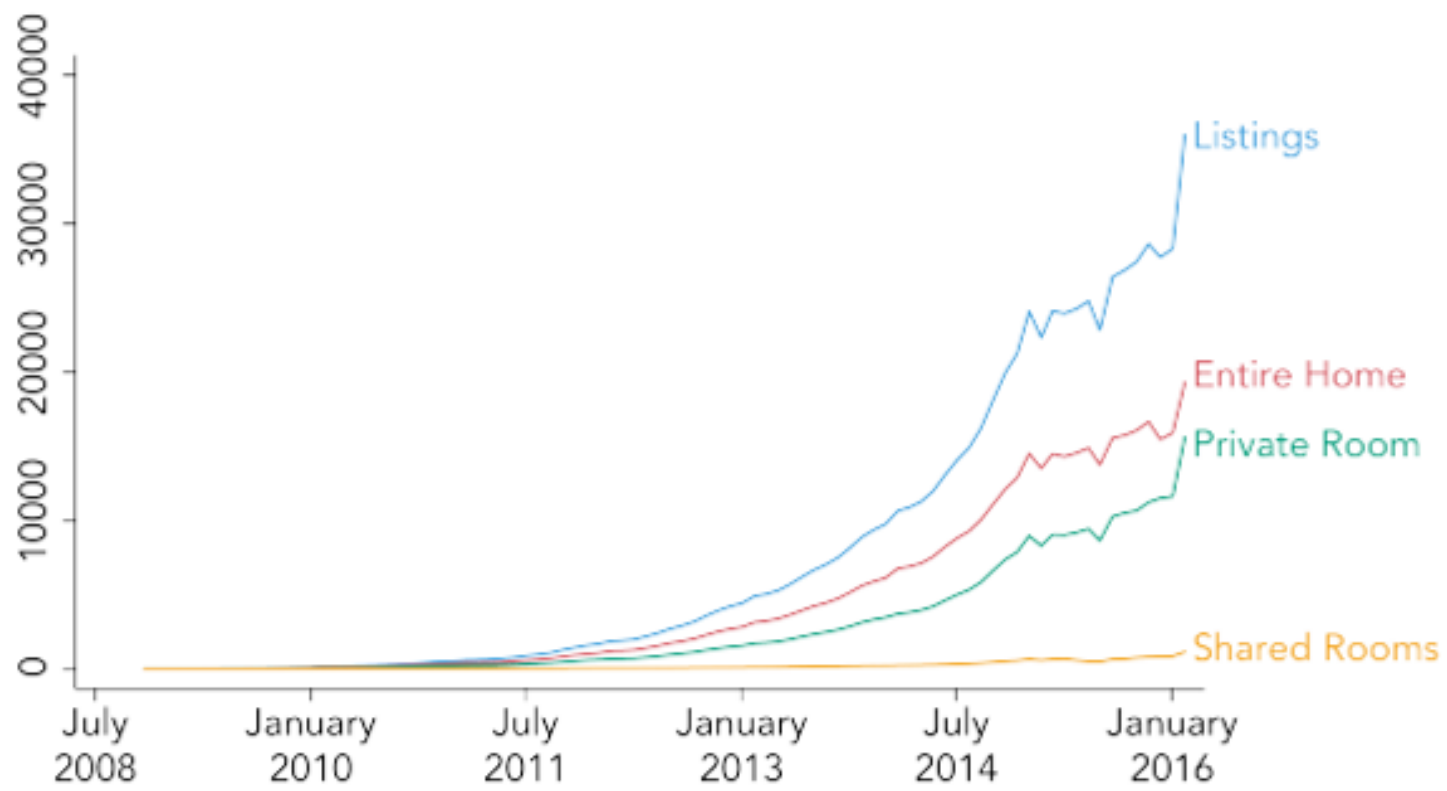

Figure 1. Airbnb platform listings from inception until 2016 [3]

\section{LITERATURE REVIEW \\ The impact of Airbnb on the Romanian real estate market}

The increase in the popularity of renting residential properties for tourism purposes, as well as the desire to enter this profitable market, have aroused the interest of potential buyers/ investors.

According to a British study, the apartments in Bucharest have among the fastest update rates in the world.

Nested discovered that the Airbnb system is substantially changing the rental market at a global level. For example, if an someone makes an investment of approx. 160.000 euros in a 4-room apartment in Bucharest, this will repay the investment in 263 months, at a rent of approx. 600 euros/month. However, if the apartment is listed on the Airbnb platform, the rental price is approx. 3500 euros/month, resulting in a depreciation rate of 46 months.

According to the same study, the rate of return on investment through Airbnb is better in Bucharest than in Dubai, Cairo or Athens. The city of Durban (South Africa) ranks first with only 18 months needed to recover an investment of 88,400 euros. The last place is occupied by Beijing, with a 714-month period needed to recover an investment of 1.26 million euros, using the Airbnb platform [8].

There are over 500 homes listed on Airbnb just in Bucharest [9].

A study conducted by the National Institute of Statistics shows that even though Sibiu is a city visited by tourists, the accommodation period is not very long. "The average length of stay in the Central Region of Romania, in April 2019 was of 1.92 days, and at the county level, the longest stay was recorded in Covasna (3.48 days), and the shortest in Sibiu county. (1.68 days)", is shown in the NIS study, conducted in April 2019 [11].

According to the data provided by the National Institute of Statistics, last year, more than 12.8 million tourists were accommodated in the tourist reception units, with approx. 750,000 more than in 2017. Of the 12.8 million foreign tourists, 1.21 million were accommodated in Bucharest, thus registering an increase compared to the previous year [11].

Bucharest ranks first with over two million tourists accommodated in 2018, followed by Brasov (1.36 million) and Constanta (1.31 million). Sibiu is in the second part of the ranking, occupying the sixth position, followed by Prahova, Bihor and Suceava, all with significant increases compared to 2017 [11]. 
Table 1. The mechanism for transmitting the impact of Airbnb activity on the real estate market

\begin{tabular}{lcc}
\hline \multicolumn{1}{c}{ The impact of Airbnb } & $\begin{array}{c}\text { The transmission } \\
\text { mechanism }\end{array}$ & $\begin{array}{c}\text { The impact on the value of } \\
\text { the property }\end{array}$ \\
\hline $\begin{array}{l}\text { The income or revenue streams appear new } \\
\text { or revenue increases }\end{array}$ & $\begin{array}{c}\text { Need for larger space } \\
\text { (maintenance or rental costs } \\
\text { decrease) }\end{array}$ & $\begin{array}{c}\text { Increase the value of the } \\
\text { property }\end{array}$ \\
$\begin{array}{l}\text { The increase in the number of rental } \\
\text { applications is due to the increase in the } \\
\text { number of tourists and residents }\end{array}$ & $\begin{array}{c}\text { The increase in demand for } \\
\text { new spaces }\end{array}$ & $\begin{array}{c}\text { Increasing the quality of the } \\
\text { neighborhood }\end{array}$ \\
$\begin{array}{l}\text { Locating the economic impact of tourists } \\
\text { Negative effects due to the tourist presence } \\
\text { (safety, flooding etc.) }\end{array}$ & $\begin{array}{c}\text { Decreased neighborhood } \\
\text { quality }\end{array}$ & $\begin{array}{c}\text { Decreased the value of the } \\
\text { property }\end{array}$ \\
\hline
\end{tabular}

\section{Legal framework}

One of the main problems faced by the owners who list their properties is represented by taxes. The income obtained from renting properties in Romania is subject to taxes, regardless of the tax residence status. At national level, any owner can list their apartment on Airbnb type platforms.

According to the Romanian tax legislation, there are three types of income obtained by owners:

- from the rental and leasing of assets;

- from the rental and leasing of fixed assets;

- from renting rooms located in homes, personal

property (with tourist accommodation capacity,

having between one and five rooms included).

The owners who obtain income from renting rooms for tourism purposes, rooms located in homes that are their personal property, need to pay to the state an annual tax of $10 \%$ from the total obtained income. The physical persons who achieve income from renting and leasing properties, and who carry out more than 5 rental contracts or obtain income from tourism purposes rental of the rooms located in homes that are their personal property, but which have an accommodation capacity greater than 5 rooms available for rent, is considered to be income obtained from independent activities. There are no specific provisions for short-term rental activities.

According to the legislation in force, a landlord cannot rent his home for tourism purposes, for more than 30 days per year without owning a tourism authorization.
According to Law no. 230/2007, changing the destination of dwellings, as well as of those having a different designation, other than that of a dwelling or of the initial purpose, can only be made with the approval of the executive committee and the acceptance of the neighboring landlords which are directly affected (horizontally and vertically).

\section{THEORETICAL PERSPECTIVES}

According to the researchers from Appraisal Journal, the properties that generate income from tourism rental have aroused interest since 2012 . At an international level, most appraisers assess a single-family property by using the market approach, trying to cope with the limitations of this method. In order to be able to apply the market approach, it is required to have a rather large number of comparable properties. It is quite difficult to find this type of data, given the incipient phase of this new trend. The small number of transactions makes the market approach become less reliable. The alternative would be to apply the cost approach, but this can cause serious problems if the real estate market is declining or if there are fluctuations in land or construction costs.

When estimating the value of a real estate property, I would include these properties in a category of complex properties. Being a relatively new practice in Romania, in order to assess these complex properties, I consider necessary to collaborate either with another appraiser or with a real estate agent, in order to complete the assessment process. This does not represent a rule, 
but we must bear in mind that these dwellings can be part of both new and old buildings.

What is the interest in assessing these properties?

Let's take for example the following scenario: if we consider a single-family property, whose owners use it from Monday to Thursday, and they rent it during the weekends for tourism purposes, then we should first start by analyzing the property from a legal point of view. I am referring to the legislation in force, authorizations regulations, if the type of construction allows rental for tourism purposes or if certain restrictions are imposed.

As an appraiser, you can consider yourself lucky if you work in a real estate market and you identify recent transactions of properties used to produce additional income from tourism rental. But the reality illustrates a lack of information regarding the properties registered on various platforms for tourism purpose and thus leading to a more difficult assessment process. Currently, in the existing databases with traded real estate properties, are not included, as a new subcategory, the properties that obtain income from tourism rental.

One option to identify and select comparable properties is to access the online home sharing platforms, thus generating a list of comparable properties.

The market approach is based on recent transactions and reflects the speculative opinions on predictive values and the influence on interest rates.

There are also other alternatives, such as the income approach or the cost approach. For the cost approach, the actual age of the buildings must be analyzed, because the older they are, the more uncertain are the obtained results.

The assessments made on the income approach are a starting point for commercial and investment properties, and even for some residential ones. Any property that generates an income, is suitable for this type of approach, therefore the real estate appraiser can obtain an indication of the worth of the income produced by a property, transforming the anticipated income (i.e. cash flow) into a value.

While the method of income capitalization and other fundamental analysis can successfully be made part of the current practices of real estate assessment, there are still some unanswered questions regarding the evaluation of real estates that generate income tourism purposes rental. A property that provides income obtained from tourism purposes rental creates a contradictory aspect, a property produces one or more incomes in a single-family residential area. Although, from a legal point of view, the exploitation is allowed, it might be the case for certain uses to arise, which are not in compliance with the legislation in force (i.e. for condominium dwellings, renting for tourism purposes requires the agreement of the association of owners). As a result of all these dynamics, real estate appraisers may become restrictive with the contributory values for such complex properties to the point of jeopardizing the evaluations.

This research relied on questions that could highlight how these properties are perceived in the real estate market:

- What are the features of the properties that generate rental income from tourism purposes?

- How high is the percentage with which this type of income contributes to the value of the property?

- What is the variability degree (higher, same or lower) of the property's value compared to the sale price?

There are several ways that can be used to estimate the income-based value. In order to develop a method that tackles the abovementioned research questions, but which could also be applied in the current evaluations, we will consider the following:

- the method should not rely on comparable properties. Currently, these types of properties are relatively rare, thus cannot provide the necessary and sufficient information;

- estimating the value of a complex property depends on knowing a specific trading price for it. For the research work, the current trading prices are real, although in practice, real estate appraisers don't always have access to these prices, for various reasons.

An appraiser can apply this method relying on the evaluation standards, within a reasonable time-frame. In addition to current trading prices, there are also other details available that may influence the perceptions on value. The purpose is to support the evaluation only based on the categories of information available to the real 
estate appraisers (e.g. public property data and real estate market data).

By using the income approach, we could obtain a perspective on these questions Bucharest is a favorable area for this study, due to the large number of apartments listed on the Airbnb platform. An analysis of the best use is also needed.

For the real estate appraiser, the results obtained after applying the income approach, demonstrates that this approach can provide an objective perspective for comparing sales when the property in discussion generates an income from tourism purposes.

\section{Conclusion}

The emergence of Airbnb platforms is an important step towards the real estate market, in terms of new experiences.

Airbnb is an innovative accommodation product that managed to change the view on hospitality throughout the entire tourism industry. The services provided by Airbnb offer homeowners the possibility to manage their own property for tourism renting purposes. This leads to an increased number of offers and the diversity of available rental properties, and to the way in which consumers will not have to opt for the purchase of a property. This trend is a favorable aspect of the real estate rental market.

The popularity of the holiday rental market has led to an increase in the supply of accommodation places and to the increase in the price of long-term rentals. The tendency is for landlords to no longer accept a lower monthly rent when they can earn double through Airbnb type platforms.

Another aspect on how Airbnb platforms impact the real estate rental market, arises from the difference between the tourism industry and real estate investments, and the difference between tenants and tourists. In conclusion, we deal with two different categories of clients.

However, there are certain limitations to this study. The use of properties taken from the home-sharing sites has an impact on the real estate offers. This research points out to various possible directions for future research. It would be beneficial to achieve an in-depth understanding of the process of evaluating complex properties, in order to better display how a tourism rental income is estimated.

The properties generating a rental income from tourism can end up, on a large scale, being misunderstood by the real estate appraisers. Apart from the social and environmental benefits that they can provide, complex properties have a potential for income, and when revenues are the basis of an evaluation, the perceptions about the value of these properties can change substantially.

Real estate appraisers need an alternative to the market approach. By applying the revenue approach, the assessors can gain more confidence and obtain perhaps a higher number of evaluation reports for this new form of development. In conclusion, this study suggests two possibilities: a value increase for the properties located in urban areas and an increase in usability.

\section{References}

1. Boizot W (2019). The Inn thing. Valuation Magazine Q1 2019:28-29 https://www.appraisalinstitute.org/ advocacy/washington-report/q1-2019-washingtonreport/

2. Brown MJ, Watkins T (2012). Understanding and Appraising Properties with Accessory Dwelling Units. The Appraisal Journal, p. 297-309

3. Law no. $230 / 2007$

4. Sheppard S, Udell A (2018). Do Airbnb properties affect house prices?. https://web.williams.edu/Economics/ wp/SheppardUdellAirbnbAffectHousePrices.pdf

5. https://airbnbinromania.ro/2019/07/23/cumfunctioneaza-airbnb/

6. https://media.imopedia.ro/stiri-imobiliare/studiuapartamente-bucuresti-24235.html

7. https://pressone.ro/sectiuni/cat-de-profitabila-esteinchirierea-locuintei-in-regim-hotelier/

8. https://smarters.ro/grow/ghid-growth-hacking/ exemplu-growth-hacking-airbnb/

9. http://www.turnulsfatului.ro/2019/07/16/airbnbtrage-obloanele-la-sibiu-ce-alternative-au-proprietariiapartamentelor/

10. www.airbnb.com

11. www.appraisalinstitute.org 